\title{
ANALISIS DAMPAK PROGRAM PEMBERDAYAAN MASYARAKAT (COMMUNITY DEVELOPMENT) PT. SUMBAWA TIMUR MINING (STM) TERHADAP KEHIDUPAN SOSIAL-EKONOMI MASYARAKAT
} (Studi Kasus Di Kecamatan Hu,u Kabupaten Dompu)

Oleh :

Ramadhoan

Ramadhoan.dompu@gmail.com

STIE YAPIS DOMPU

\begin{abstract}
The purpose of this study was to analyze the impact of community empowerment programs conducted by PT. STM to the social and economic life of society, both directly and indirectly. The method used is a qualitative and quantitative data collection techniques using observation method, the method of documentation, interview and questionnaire. Technical analysis of the data used in the method of qualitative research is data reduction, data display and conclusion; Technical analysis of the data that is used mainly on quantitative methods are counting frequency. The results showed that in terms of direct benefits, the vast majority of corporate social responsibility is embodied in the form of community empowerment program very useful. However, if the terms of the indirect benefits of community empowerment programs implemented by the company is still less perceived benefits. This can be understood as the activities carried out by PT. East Sumbawa Mining (STM) are still at the exploratory stage and given the share of allocation of funds spent on community empowerment program is still relatively small compared to the total allocation of development funds in the District of Hu'u. Social impact is more felt by the people than the economic impact. It is due to that ComDev in economics is relatively small when compared to the social sector, both in terms of budget as well as routine and sustainability programs.
\end{abstract}

Keyword: Empowering the community, social and economic impact, PT.STM

\begin{abstract}
ABSTRAK
Tujuan penelitian ini adalah untuk menganalisis dampak program pemberdayaan masyarakat yang dilaksanakan oleh PT. STM terhadap kehidupan sosial-ekonomi masyarakat baik secara langsung maupun tidak langsung. Metode penelitian yang digunakan adalah kualitatif dan kuantitatif, Teknik pengumpulan data menggunakan metode observasi, metode dokumentasi, metode wawancara dan metode kuesioner. Tehnik analisis data yang digunakan pada metode penelitian kualitatif adalah reduksi data, menampilkan data dan penarikan kesimpulan; Tehnik analisis data yang digunkan pada metode kuantitatif adalah menghitung frekuensi. Hasil penelitian menunjukan bahwa ditinjau dari manfaat secara langsung, sebagian besar dari tanggung jawab sosial perusahaan yang diwujudkan dalam bentuk program pemberdayaan masyarakat sangat dirasakan manfaatnya. Namun kalau ditinjau dari manfaat tidak langsung program
\end{abstract}


pemberdayaan masyarakat yang dilaksanakan oleh perusahaan masih kurang dirasakan manfaatnya. Hal tersebut bisa dipahami karena aktivitas yang dilakukan oleh PT. Sumbawa Timur Mining (STM) masih pada tahap eksplorasi dan mengingat pangsa alokasi dana yang dikeluarkan pada program pemberdayaan masyarakat tersebut masih relatif kecil jika dibandingkan dengan total alokasi dana pembangunan di wilayah Kecamatan Hu'u. Dampak secara sosial lebih dirasakan oleh masyarakat dibandingkan dengan dampak secara ekonomi. Hal ini disebabkan bahwa program Comdev di bidang ekonomi relatif sedikit bila dibandingkan dengan bidang sosial, baik dari segi anggaran maupun rutinitas dan keberlanjutan programnya.

Keyword: Pemberdayaan masyrakat, Dampak sosial dan ekonomi, PT.STM

\section{PENDAHULUAN}

Industrialisasi merupakan upaya sadar dan terencana dalam rangka mengelola dan memanfaatkan sumber daya guna mencapai tujuan pembangunan yakni meningkatkan kualitas kehidupan masyarakat dan bangsa. Pembangunan pertambangan merupakan bagian integral dari, pembangunan nasional dalam rangka mewujudkan cita-cita bangsa mencapai masyarakat adil dan makmur yang merata.

Keberadaan perusahaan tambang di tengah-tengah masyarakat merupakan wujud dan partisipasi dalam peningkatan dan pengembangan pembangunan masyarakat. Perusahaan dan masyarakat yang bermukim di sekitarnya merupakan dua komponen yang saling mempengaruhi. Secara general perusahaan tambang memberikan dampak kepada masyarakat sehingga perlu diukur sejauhmana pengaruh tersebut.

PT STM mendapat kontrak explorasi dengan target utama mendapatkan deposit tembaga (Cooper) dari Kementrian Energi Sumberdaya Daya Mineral (ESDM) dengan Total luas areal explorasi 19.620 hektar. Selama melakukan tahap eksplorasi PT. STM melaksanakan suatu program pemberdayaan masyarakat (Comunity Development) sebagai bentuk tanggung jawab sosial perusahaan (CSR).

Tujuan dari penelitian ini adalah untuk menganalisis manfaat ekonomi dan sosial-ekonomi langsung dan tidak langsung dari kegiatan Hu'u Copper Project (Proyek Tembaga Hu'u)g sejak 
dimulainya pekerjaan pada tahun 2011 hingga 2014

\section{METODELOGI PENELITIAN}

Penelitian menggunakan gabungan kedua jenis penelitian yaitu jenis penelitian kualitatif dan jenis penelitian kuantitatif. Pendekatan penelitian deskriptif kualitatif adalah semua data yang diperoleh dideskripsikan apa adanya berdasarkan kondisi di lokasi penelitian. Sedangkan penelitian kuantitatif adalah menguraikan datadata dalam bentuk angka-angka atau diolah dengan rumus stastisk.

Dalam penelitian ini, penulis berusaha mendeskripsikan atau menggambarkan data-data yang telah diperoleh dari wawancara, observasi dan penelusuran pustaka. Penelitian dirancang dalam tiga tahapan berdasarkan tujuan yang ingin dicapai.

Adapun tahapan penelitian ini adalah sebagai berikut :

a. Menggali informasi secara langsung tentang keberadaan dan aktivitas yang dilakukan oleh PT. STM

b. Mengkaji implementasi program Pengembangan Masyrakat (Comunity Develoment) yang dilakukan oleh PT STM terhadap masyarakat sekitar tambang.

c. Mengkaji secara mendalam dampak yang ditimbulkan dari setiap program pemberdayaan masyarakat dilihat dari aspek sosial dan ekonomi

Pengambilan sumber data/sampel dalam penelitian dengan Purposive Sampling atau dengan pertimbangan tertentu. Beberapa pertimbangan dalam menentukan responden kunci yang akan dijadikan sumberdata/responden, menggunakan kriteria seperti berikut:

a. Penerima program comdev PT. STM

b. Penentu kebijakan terhadap program comdev PT. STM

c. Merasakan dampak langsung atau tidak langsung terhadap program pemberdayaan masyarakat PT. STM

d. Manajemen PT. STM (Sumbawa Timur Mining )

e. Pemangku kepentingan (Stakeholders)

Teknik analisis yang digunakan pada penelitian ini adalah secara kuantitatif yaitu meghitung 
porsentase jawaban responden dengan cara menganalisa frekuensi jawaban dari responden dengan menggunakan bantuan shoftwhare SPSS. Dan secara kualitatif penulis memilih Model Miles dan Huberman.

\section{PEMBAHASAN}

Program

pemberdayaan

masyarakat yang

telah

dilaksanakan

Program

Community

Development yang dilakukan PT. STM di Kecatan Hu'u terdiri dari tujuh (7) program Pemberdayaan Masyarakat

(Community

Development) yaitu: 1). Pendidikan dan kesehatan, 2) Infrastruktur dan air bersih, 3) Pertanian dan peternakan, 4) Sponsorship, 5) Community Small Grant (Hibah untuk masyarakat), 6) Pelatihan kejuruan, dan 7) pelatihan pemberdayaan masyarakat yang baru dilakukan pada tahun 2014 .

Dari ketujuh program Comdev yang dilakukan oleh PT. STM. Dalam penelitian ini hanya difokuskan pada lima bidang program yaitu:

\section{Pendidikan dan Kesehatan}

Program - program yang telah dilaksanakan pada bidang pendidkan dan kesehatan sebagai berikut :

\section{a. Pendidikan}

Program - program yang telah dilaksanakan oleh PT. STM pada bidang pendidkan adalah :

1) Program Keaksaraan Usaha Mandiri yang meliputi; 1) pemberantasan buta aksara; 2) pelatihan pembuatan abon dan bakso dari ikan; 3) pelatihan kerajinan.

2) Peningkatan keahlian guruguru Sekolah Dasar (SD)

3) Penyediaan buku-buku wajib SD dan SMP

4) Workshop untuk guru-guru PAUD

5) Penyediaan peralatan dan perlengkapan pendidikan untuk PAUD

6) Bantuan memperbaiki gedung PAUD

7) Bantuan meja dan kursi di SD N $04 \mathrm{Hu}$ 'u

\section{b. Kesehatan}

1) Program pemeriksaan kesehatan dan penyediaan makanan tambahan 
2) Penyediaan fasilitas untuk kampanye Hidup Sehat dan Bersih

3) Workshop untuk kader Posyandu sekecamatan Hu'u

4) Bantuan untuk monitoring program oleh konsultan

5) Bantuan untuk sosialisasi program kesehatan

6) Pemeberian makanan tambahan (Oktober Desember 2012)

7) Penyediaan fasilitas dan perlengkapan untuk Posyandu

8) Pendidikan kesehatan untuk ibu-ibu dan bayi

\section{Infrastruktur dan Air Bersih}

Program - program yang telah dilaksanakan pada bidang infrastruktur dan air bersih sebagai berikut :

1) Perbaikan bak air bersih di desa Rasabou, Marada dan Daha

2) Pembangunan saluran irigasi tersier sepanjang 200 meter di 8 desa Kec.Hu'u

3) Konsultan untuk infrastruktur dan air bersih

\section{Pertanian dan peternakan}

Program - program yang telah dilaksanakan pada bidang Pertanian dan peternakan sebagai berikut :

1) Pelatihan manajemen peternakan

2) Program Kawasan Rumah Pangan Lestari (K-RPL)

\section{Pelatihan Kejuruan}

Program - program yang telah dilaksanakan pada bidang Pelatihan kejuruan sebagai berikut :

1) Pelatihan montir sepeda motor dan menjahit

2) Pelatihan memperbaiki jaring dan jala ikan

3) Pelatihan Pemanfaatan sabut kelapa dan pembuatan minyak kelapa murni (virgin coconut oil)

4) Kerajinan tangan menyulam dan membuat bross

\section{Pelatihan Pemberdayaan}

\section{Masyarakat}

1. Partisipasi perempuan dalam peningkatan kesejahteraan keluarga 
2. Pengembangan kerjasama dan kemitraan bagi pembangunan lokal

3. Kewirausahaan dan pengembangan usaha kecil

4. Pengolahan ikan

5. Pengolahan tahu dan tempe

\section{Tingkat Manfaat Lima Program Pemberdayaan Masyrakat}

Dari kelima kategori manfaat, bahwa frekuensi jawaban responden memiliki tingkat porsentase yang berbeda-beda beda, berikut porsentase jawaban responden dari tiap bidang program pemberdayaan masyrakat yaitu :

\section{Bidang Pendidikan}

Tingkat manfaat yang dirasakan oleh masyarakat dari program-program Comdev pada bidang pendidikan ditunjukan pada tabel 1

Tabel 1. Tingkat Manfaat Program-Program Pada Bidang Pendidikan

\begin{tabular}{lrrrrr}
\hline & Frequency & Percent & $\begin{array}{c}\text { Valid } \\
\text { Percent }\end{array}$ & $\begin{array}{c}\text { Cumulative } \\
\text { Percent }\end{array}$ \\
\hline Valid & 2 Kurang Bermanfaat & 1 & 3,2 & 3,2 & 3,2 \\
\hline 3 Cukup Bermanfaat & 8 & 25,8 & 25,8 & 29,0 \\
\hline 4 Bermanfaat & 18 & 58,1 & 58,1 & 87,1 \\
\hline 5 Sangat Bermanfaat & 4 & 12,9 & 12,9 & 100,0 \\
\hline Total & 31 & 100,0 & 100,0 & \\
\hline
\end{tabular}

Sumber : data diolah dengan menggunakan SPSS

Dari data diatas menunjukan bahwa tingkat manfaat yang dirasakan oleh masyarakat melalui persepsi responden adalah sebanyak 2 orang yang mengatakan kurang bermanfaat atau sekitar 3,2\%, 8 orang mengatakan cukup bermanfaat atau sekitar 25,8\%, sebanyak 18 orang mengatakan bermanfaat atau sekitar $58,1 \%$ dan sebanyak 4 orang yang mengatakan sangat bermanfaat atau sekitar $12,9 \%$ dari total responden.

Jadi secara kumulatif dapat ditarik suatu kesimpulan bahwa program-program pada bidang pendidikan dapat dikatakan bermanfaat bagi masyarakat hal ini ditunjukan bahwa sebanyak 58,1\% responden mengatakan bermanfaat. Hasil tersebut sejalan dengan hasil penelitian yang jelaskan secara kualitatif dari data-data yang yang 
dikumpulkan di lapangan dan telah diuraikan di atas bahwa semua program memiliki tingkat manfaat masing-masing dengan berbagai capaian dan kendala yang dihadapi.

Bahwa program-program yang telah dilaksanakan pada bidang pendidikan secara lansung memberikan manfaat yang dapat dirasakan oleh penerima manfaat walaupun secara tidak langsung masih relatif kecil dirasakan. Hal ini diperkuat berdasarkan temuan bahwa manfaat yang dirasakan tersebut hanya pada tingkat penerima manfaat dan belum meberikan kontribusi manfaat secara luas (makro).

\section{Bidang Kesehatan}

Berikut tingkat manfaat yang dirasakan oleh masyarakat dari program-program Comdev pada bidang kesehatan yang ditunjukan pada tabel 2.

Tabel 2. Tingkat manfaat yang dirasakan pada bidang Kesehatan

\begin{tabular}{llrrrr}
\hline & Frequency & Percent & $\begin{array}{c}\text { Valid } \\
\text { Percent }\end{array}$ & $\begin{array}{c}\text { Cumulativ } \\
\text { e Percent }\end{array}$ \\
\hline Valid & 1 & 3,2 & 3,2 & 3,2 \\
\hline & 2 Kurang Bermanfaat & 7 & 22,6 & 22,6 & 25,8 \\
\hline 3 Cukup Bermanfaat & 19 & 61,3 & 61,3 & 87,1 \\
\hline 4 Bermanfaat & 4 & 12,9 & 12,9 & 100,0 \\
\hline 5 Sangat Bermanfaat & 31 & 100,0 & 100,0 & \\
\hline Total & &
\end{tabular}

Sumber : SPSS yang input dari Microsoft Exel (Diolah)

Dari data di atas menunjukan bahwa tingkat manfaat yang dirasakan oleh masyarakat melalui persepsi responden adalah sebanyak 1 orang mengatakan kurang bermanfaat atau sekitar $3,2 \%, 7$ orang yang mengatakan cukup bermanfaat atau sekitar 22,6\%, 19 orang mengatakan bermanfaat atau sekitar $61,3 \%$, dan sebanyak 4 orang yang mengatakan sangat bermanfaat atau sekitar $12,9 \%$ dari total responden.
Jadi secara komulatif dapat ditarik suatu kesimpulan bahwa program -program pada bidang kesehatan dapat dikatakan bermanfaat bagi masyarakat, hal ini dibutikan bahwa $61,3 \%$ responden mengatakan bermanfaat. Hasil tersebut sejalan dengan hasil penelitian yang jelaskan secara kualitatif dari data-data yang yang dikumpulkan dilapangan dan telah diuraikan di atas bahwa masyarakat 
sangat merasakan manfaat dari dari program-program Comdev program bntuan tersebut.

\section{Bidang Infrastruktur Dan Air} pada bidang ditunjukan pada Bersih tabel 3 .

$$
\begin{array}{r}
\text { Berikut tingkat manfaat } \\
\text { yang dirasakan oleh masyarakat }
\end{array}
$$

Tabel 3. Tingkat Manfaat pada Bidang Infrastruktur dan Air Bersih

\begin{tabular}{lrrrrr} 
& & Frequency & Percent & $\begin{array}{c}\text { Valid } \\
\text { Percent }\end{array}$ & $\begin{array}{c}\text { Cumulati } \\
\text { ve } \\
\text { Percent }\end{array}$ \\
\hline Valid & 3 Cukup Bermanfaat & 7 & 22,6 & 22,6 & 22,6 \\
\hline 4 Bermanfaat & 21 & 67,7 & 67,7 & 90,3 \\
\hline 5 sangat Bermanfaat & 3 & 9,7 & 9,7 & 100,0 \\
\hline Total & 31 & 100,0 & 100,0 & \\
\hline
\end{tabular}

Sumber : SPSS yang input dari Microsoft Exel (Diolah)

Dari data di atas menunjukan bahwa tingkat manfaat yang dirasakan oleh masyarakat melalui persepsi responden adalah sebanyak 7 orang yang mengatakan cukup bermanfaat atau sekitar 22,6\%, 21 orang mengatakan bermanfaat atau sekitar $67,7 \%$, dan sebanyak 3 orang yang mengatakan sangat bermanfaat atau sekitar 9,7\%.

Jadi secara kumulatif dapat ditarik kesimpulan bahwa program program pada bidang infrastruktur dan air bersih dapat dikatakan bermanfaat bagi masyarakat itu ditunjukan bahwa sebanyak $67 \%$ responden mengatakan bermanfaat. Hasil tersebut sejalan dengan hasil penelitian yang jelaskan secara kualitatif dari data-data yang yang dikumpulkan dilapangan; bahwa secara manfaat dari programprogram pada bidang infrastruktur dan air bersih adalah tersedianya tempat penampungan air dalam pemenuhan kebutuhan dan tersedianya saluran irigasi dalam menunjang kelancaran pengairan tanamanan pertanian masyrakat.

\section{Pertanian dan Peternakan}

Tingkat manfaat yang dirasakan oleh masyarakat dari program-program Comdev pada bidang pertanian dan peternakan ditunjukan pada tabel 4. 
Tabel 4. Pertanian dan Peternakan

\begin{tabular}{llrrrr}
\hline & Frequency & Percent & $\begin{array}{c}\text { Valid } \\
\text { Percent }\end{array}$ & $\begin{array}{c}\text { Cumulativ } \\
\text { e Percent }\end{array}$ \\
\hline Valid & 1 Tidak Bermanfaat & 4 & 12,9 & 12,9 & 12,9 \\
\hline 2 Kurang Bermanfaat & 6 & 19,4 & 19,4 & 32,3 \\
\hline 3 Cukup Bermanfaat & 8 & 25,8 & 25,8 & 58,1 \\
\hline 4 Bermanfaat & 10 & 32,3 & 32,3 & 90,3 \\
\hline 5 Sangat Bermanfaat & 3 & 9,7 & 9,7 & 100,0 \\
\hline Total & 31 & 100,0 & 100,0 & \\
\hline
\end{tabular}

Sumber : SPSS yang input dari Microsoft Exel (Diolah)

Dari data di atas menunjukan bahwa tingkat manfaat yang dirasakan oleh masyarakat melalui persepsi responden adalah sebanyak 4 orang yang mengatakan tidak bermanfaat atau sekitar 12,9\%, 6 orang mengatakan kurang bermanfaat atau sekitar 19,4\%, dan sebanyak 8 orang yang mengatakan cukup bermanfaat atau sekitar $25,8 \%$, dan sebanyak 10 orang mengatakan bermanfaat atau sekitar $32,3 \%$ dari total responden.

Jadi dapat ditarik suatu kesimpulan bahwa program-program pada bidang pendidikan dan pertanian dapat dikatakan variatif namun sebagian besar responden mengatakan bahwa program tersebut bermanfaat bagi masyarakat. Hasil tersebut sejalan dengan hasil penelitian yang jelaskan secara kualitatif dari data-data yang yang dikumpulkan di lapangan, bahwa dari segi pelaksanaan program dan hasil yang ingin dicapai belum maksimal dirasakan manfaat oleh masyarakat secara umum, namun demikian manfaat terhadap penerima program bisa dirasakan dalam peningkatan pengetahuan dan keterampilannya.

\section{Bidang Pelatihan Kejuruan}

Tingkat manfaat yang dirasakan oleh masyarakat dari program-program Comdev pada 
bidang pertanian dan peternakan ditunjukan pada tabel 5.

Tabel 4. Pelatihan Kejuruan

\begin{tabular}{|c|c|c|c|c|c|}
\hline & & Frequency & Percent & $\begin{array}{c}\text { Valid } \\
\text { Percent }\end{array}$ & $\begin{array}{l}\text { Cumulativ } \\
\text { e Percent }\end{array}$ \\
\hline \multirow[t]{4}{*}{ Valid } & 3 Cukup Bermanfaat & 11 & 35,5 & 35,5 & 35,5 \\
\hline & 4 Bermanfaat & 15 & 48,4 & 48,4 & 83,9 \\
\hline & 5 Sangat Bermanfaat & 5 & 16,1 & 16,1 & 100,0 \\
\hline & Total & 31 & 100,0 & 100,0 & \\
\hline
\end{tabular}

Sumber : data diolah dengan menggunakan SPSS

Dari data di atas menunjukan bahwa tingkat manfaat yang dirasakan oleh masyarakat melalui persepsi responden adalah sebanyak 11 orang yang mengatakan cukup bermanfaat atau sekitar 35,5\%, 15 orang mengatakan bermanfaat atau sekitar 48,4\%, dan sebanyak 5 orang yang mengatakan sangat bermanfaat atau sekitar $16,1 \%$ dari total responden.

Jadi secara kumulatif dapat ditarik suatu kesimpulan bahwa program-program pada bidang kejuaruan dapat dikatakan bermanfaat bagi masyarakat itu ditunjukan bahwa sebanyak $48 \%$ responden mengatakan bermanfaat. Hasil tersebut sejalan dengan hasil penelitian yang jelaskan secara kualitatif dari data-data yang yang dikumpulkan di lapangan dan telah diuraikan di atas bahwa semua program memiliki tingkat manfaat masing-masing dengan berbagai capaian dan kendala yang dihadapi. Namun secara umum berdasarkan temuan bahwa secara langsung manfaanya dirasakan oleh peserta penerima program, namun secara umum masih relatif kecil dirasakan.

\section{Pelatihan Pemberdayaan}

\section{Masyratakat}

Tingkat manfaat yang dirasakan oleh masyarakat dari program-program Comdev pada bidang pelatihan pemberdayaan masyarakat dapat dilihat dalam tabel 6. 
Tabel 6 .Tingkat Manfaat Bidang Pelatihan Pemberdayaan Masyarakat

\begin{tabular}{lrrrrr}
\hline & $\begin{array}{c}\text { Frequ } \\
\text { ency }\end{array}$ & Percent & $\begin{array}{c}\text { Valid } \\
\text { Percent }\end{array}$ & $\begin{array}{c}\text { Cumulative } \\
\text { Percent }\end{array}$ \\
\hline Valid & 2 Kurang bermanfaat & 4 & 12,9 & 12,9 & 12,9 \\
\hline 3 Cukup Bermanfaat & 6 & 19,4 & 19,4 & 32,3 \\
\hline 4 Bermanfaat & 13 & 41,9 & 41,9 & 74,2 \\
\hline 5 Sangat Bermanfaat & 8 & 25,8 & 25,8 & 100,0 \\
\hline Total & 31 & 100,0 & 100,0 & \\
\hline
\end{tabular}

Sumber : SPSS yang input dari Microsoft Exel (Diolah)

Dari data di atas menunjukan bahwa tingkat manfaat yang dirasakan oleh masyarakat melalui persepsi responden adalah sebanyak 4 orang yang mengatakan kurang bermanfaat atau sekitar 12,9\%, 6 orang yang mengatakan cukup bermanfaat atau sekitar 19,4\%, 13 orang mengatakan bermanfaat atau sekitar $41,9 \%$, dan sebanyak 8 orang yang mengatakan sangat bermanfaat atau sekitar 25,8\%.

Jadi secara kumulatif dapat ditarik suatu kesimpulan bahwa program-program pada bidang pelatihan pemberdayaan masyarakat dapat dikatakan bermanfaat bagi masyarakat. Hasil tersebut sejalan dengan hasil penelitian yang jelaskan secara kualitatif bahwa masyrakat penerima manfaat belum mampu mengaplikasikan pengetahuan, kemampuan dan keterampilan yang didapat dengan berbagai alasan seperti, permodalan, akses pemasaran, dukungan infrastruktur dan lain-lain.

Dari kelima kriteria kebermanfaatnya bahwa semua bidang program berada pada frekuensi jawaban Bermanfaat dengan tingkat porsentase yang berbeda-beda beda, berikut urutan prosentase dari tiap bidang program tersebut yaitu :

1. Infrastruktur dan air bersih $(67,7 \%)$

2. Kesehatan $(61,3 \%)$,

3. Pendidikan $(58,1 \%)$,

4. Pelatihan Kejuruan $(48,4)$,

5. Pelatihan Pemberdayaan Masyratakat $(41,9 \%)$

6. Pertanian dan peternakan $(32,3 \%)$

Dari porsentase tersebut secara kumulatif bahwa porsentase paling tinggi pada tingkat manfaat yang dirasakan masyarakat dari enam bidang program diatas adalah bidang program infrastruktur dan air bersih. 


\section{Dampak Sosial Dan Ekonomi}

\section{Ekonomi}

\section{a) Bidang Pertanian dan peternakan}

1. Program pelatihan manajemen peternakan memiliki dampak terhadap ekonomi masyarakat sebanyak 25,8\% menjawab setuju dengan alasan meningkatnya memahaman dan pengetahuan dalam pengelolaan ternak. Sedangkan yang belum merasakan dampak ekonomi sebanyak 74,2\% dengan alasan mereka masih tetap memelihara ternak secara liar dan belum menerapkan sesuai dengan apa yang di dapat pada saat pelatihan.

2. Program kawasan rumah pangan lestari memiliki dampak secara ekonomi masyarakat sebanyak $41,9 \%$ menjawab setuju, dengan alasan dapat memenuhi kebutuhan dengan pemanfaatan lahan tersebut. Dan yang belum merasakan dampak secara ekonomi sebanyak 58,1\% dengan alasan belum memberikan pengaruh terhadap pendapatan.

\section{b) Bidang Pelatihan Kejuruan}

Pelatihan montir dan sepeda motor sebesar $28 \%$ menyatakan setuju, pelatihan memperbaiki jaring dan jala sebesar $40 \%$ menyatakan setuju, pemanfaatan sabut kelapa sebesar $24 \%$ menyatakan setuju dan kerajinan tangan menyulam dan membuat bros sebesar $36 \%$ menyatakan setuju dan yang menyatakan tidak setuju terhadap dampak terhadap ekonomi yaitu pelatihan montir dan sepeda motor sebesar $72 \%$ dengan alasan tidak diterpakan, pelatihan memperbaiki jaring dan jala sebesar $60 \%$ dengan alasan tidak berpengaruh terhadap pendapatan, pemanfaatan sabut kelapa sebesar $76 \%$ dengan lasan tidak memberikan pendapatan yang sesuai dan kerajinan tangan menyulam dan membuat bros sebesar 64\%. Dengan alasan tidak lagi diterapkan.

\section{c) Pelatihan Pemberdayaan \\ Masyratakat}

Dampak ekonomi yang dirasakan masyrakat yaitu adalah 
1) Menjawab setuju terhadap dampak ekonomi yaitu: partisipasi perempuan dalam peningkatan kesejahteraan keluarga sebesar 33,3\%, Pengembangan kerjasama dan kemitraan bagi pembangunan ekonomi lokal $33,3 \%$, kewirausahaan dan pengembangan usaha kecil sebesar $\quad 46,7 \%$ dan pengolahan ikan $40 \%$ dan pengolahan tahu dan tempe sebesar $60 \%$ responden menjawab merasakan dampak terhadap ekonomi

2) Sedangkan yang menjawab tidak setuju dalam merasakan dampak ekonomi yaitu partisipasi perempuan dalam peningkatan kesejahteraan keluarga sebesar $66,7 \%$, Pengembangan kerjasama dan kemitraan bagi pembangunan ekonomi lokal $66,7 \%$, kewirausahaan dan pengembangan usaha kecil sebesar $53,3 \%$ dan pengolahan ikan $60 \%$ dan pengolahan tahu dan tempe $40 \%$
Berdasarkan hasil penelitian secara kumulatif dampak dari program-program yang dilakukan oleh PT STM terhadap kehidupan ekonomi masyarakat masih relatif kecil dirasakan oleh masyrakat. hal ini terjadi mengingat programprogram tersebut masih belum berjalan secara maksimal sesuai dengan harapan dan belum memberikan pengaruh yang signifikan terhadap peningkatan pendapatan masyarakat, juga terdapat sebagian program-program yang telah dilaksanakan masih pada tahap pelatihan (treaning). Dan terdapat program-program yang sangat menonjol tidak berjalan dengan lancar seperti program; pelatihan manajemen peternakan, Pelatihan montir sepeda motor dan menjahit, Pemanfaatan sabut kelapa, Kerajinan tangan menyulam dan membuat bross, Pengolahan ikan, Kewirausahaan dan pengembangan usaha kecil.

\section{Sosial}

a. Inftrastruktur dan Air Bersih Dampak sosial yang
dirasakan masyrakat dari
program infrastuktur dan air
bersih yaitu yang menjawab 
setuju atas dampak sosial yang masyrakat rasakan adalah :

1. pembangunan bak air bersih manfaat secara sosialnyaa sebanyak $\quad 83,9 \quad \%$ menyatakan sutuju atas dampak sosial yang dirasakan dengan alasan dapat memenuhi kebutuhan air bersih sampai sekarang

2. saluran irigasi tersier sebanyak $71,0 \%$ yang menyatakan setuju dengan dampak sosial yang dirasakan dengan alasan aliran air dalam kebutuhan pengairan tanaman semakin lancar.

\section{b. Pendidikan}

Dampak sosial yang
dirasakan masyrakat dari
program-program pendidikan
yaitu :

1. Program Keaksaraan Usaha Mandiri sebanyak $65 \%$ menyatakan setuju dengan alasan bisa mengenal huruf, menghitung dan mengeja,

2. Peningkatan keahlian guruguru SD sebanyak $60 \%$ menyatakan setuju dengan alasan meningkatnaya pengetahuan

dan

pemahaman,

3. Penyediaan buku-buku wajib SD dan SMP, sebanyak $65 \%$ yang menyatakan setuju dengan alasan sangat dibutuhkan,

4. Workshop untuk guru-guru PAUD sebanyak $80 \%$ menyatakan setuju dengan alasan bisa menyusun rencana kegiatan dalam implementasi pengajaran sesuai dengan yang di dapat pada saat mengikuti workshop.

5. Penyediaan peralatan dan perlengkapan pendidikan untuk PAUD sebanyak $80 \%$ menyatakan setuju dengan alasan sangat dibutuhkan.

\section{c. Kesehatan}

Dampak sosial yang
dirasakan masyrakat dari
program-program kesehatan
yaitu:

1. Program pemeriksaan kesehatan dan penyediaan makanan tambahan sebanyak $55 \%$ menyatakan setuju dengan alasan dibutuhkan 
2. Penyediaan fasilitas untuk kampanye Hidup Sehat dan Bersih sebanyak 50\%, menyatakan setuju dengan alasan dibutuhkan dalam meningkatkan kesadaran masyrakat pentingnya hidup sehat dan bersih

3. Workshop untuk kader Posyandu sebanyak $60 \%$ menyatakan setuju dengan alasan melakukan pembinaan kepada masyrakat.

4. Bantuan untuk monitoring program oleh konsultan sebanyak $60 \%$ menyatakan setuju dengan alasan dibutuhkan

5. Penyediaan fasilitas dan perlengkapan untuk Posyandu sebanyak $65 \%$ menyatakan setuju dengan alasan sangan dibutuhkan, dan fasilitas bertambah

6. Pendidikan kesehatan untuk ibuibu dan bayi sebanyak $75 \%$ menyatakan setuju dengan alasan ibu-ibu semakin sadar terhadap pentingnya kesehatan ibu dan bayi

Berdasrkan urain di atas dapat disimpulkan bahwa dampak sosial yang dirasakan dari programprogram yang dilakukan oleh PT STM terhadap kehidupan sosial masyrakat sangat dirasakan oleh masyrakat khususnya individu dan kelompok-kelompok penerima program. Dari beberapa program comdev PT. STM kecamatan Hu'u yang dianggap memiliki dampak sosial masyarakat seperti pembangunan bak air bersih manfaat secara sosialnyaa sebanyak 83,9\% sedangkan saluran irigasi tersier sebanyak, Workshop untuk guruguru PAUD sebanyak 80\%, dan Penyediaan peralatan dan perlengkapan pendidikan untuk PAUD sebanyak $80 \%$. Sedangkan program relatif rendah dampak sosialnya adalah program bantuan untuk sosialisasi program kesehatan sebanyak 45\%, sedangkan sisanya relatif datar saja. Hal ini dapat dikatakan bahwa dampak sosial masyarakat dari semua program tersebut tidak hanya untuk memenuhi kebutuhan perorangan pada peningkatan pengetahuan dan ketrampilan personal tetapi juga sangat untuk kepentingan masyarakat umum atau masyarakat sekitar lingkar tambang. 
d. Perbandingan Dampak Yang Dirasakan Secara Sosial Dan Ekonomi

Dampak sosial lebih
dirasakan oleh masyarakat
dibandingkan dengan dampak
secara ekonomi. Hal ini
disebabkan bahwa program
comdev dibidang ekonomi
relatif sedikit bila dibandingkan
dengan bidang sosial. Baik dari
segi anggaran maupun rutinitas
dan keberlanjutan programnya.
Disisi lain bahwa program
dibidang ekonomi belum
dilaksanakan secara merata pada
delapan desa di kecamatan Huu
tetapi program bidang sosial
secara umum dapat menjangkau
delapan desa yang ada di
kecamatan Hu'u dan Parado.

Disisi lain bahwa semua program comdev dibidang sosial tersebut tidak hanya kepentingan sesaat perorangan tetapi merupakan investasi sumber daya yang lebih baik untuk masyarakat umum kedepan. Hal ini cukup beralasan karena dengan investasi sumber daya maka kehidupan sosial akan lebih baik di masa akan datang.
Berbeda dengan investasi dibidang ekonomi dapat dilihat secara nyata oleh masyarakat saat ini dan masa depan tetapi akan terlihat perilaku dan pola pikir masyarakat untuk menyikapi dan mengkritisi setiap persoalan yang dihadapi dalam kesehariannya.

\section{KESIMPULAN}

Berdasarkan hasil penelitian, Dirumuskan berbagai kesimpulan sebagai berikut, bahwa :

PT. Sumbawa Timur Mining (STM) telah melaksanakan Program community development sejak tahun 2011 dan masih dilanjutkan sampai sekarang.

Terdapat lima (5) bidang Program community development yang telah dikaji, diulas dan dievaluasi oleh PT. STM yaitu 1) Pendidikan dan Kesehatan; 2) Infrastuktur dan Air Bersih; 3) Pertanian dan Peternakan; 4) Pelatihan Kejuruan; dan 5) Pelatihan Pemberdayaan masyraka; Dan dari kelima bidang program tersebut terdapat program-program yang telah dilaksanakan yang merupakan bagian dari lima bidang program tersebut. 
Ditinjau dari manfaat secara langsung, sebagian besar dari tanggung jawab sosial perusahaan yang diwujudkan dalam bentuk program pemberdayaan masyarakat sangat dirasakan manfaatnya.

Secara tidak langsung program pemberdayaan masyarakat yang dilaksanakan oleh perusahaan masih kurnang dirasakan manfaatnya. Hal tersebut bisa dipahami karena aktivitas yang dilakukan oleh PT Sumbawa Timur Mining (STM) masih pada tahap eksplorasi. Mengingat pangsa alokasi dana yang dikeluarkan pada program Pemberdayaan masyarakat tersebut masih relatif kecil jika dibandingkan dengan total alokasi dana pembangunan di wilayah Kecamatan Hu'u.

\section{Program pemberdayaan} masyarakat di bidang pendidikan telah mampu meningkatkan sarana dan prasarana, pegetahuan dan motivasi guru/siswa sehingga memberikan andil terhadap perkembangan dan kemajuan pendidikan. Namun demikian dampak ini masih relatif kecil.

Program pemberdayaan masyarakat di bidang kesehatan telah memberikan dampak terhadap peningkatan pengetahuan, kepedulian, dan kesadaran masyarakat akan pentingnya aspek kesehatan. Di sisi yang lain masih terdapat sebagian masyarakat yang menganggap aspek kesehatan bukan menjadi prioritas.

Program pemberdayaan masyarakat di bidang infrastruktur dan air bersih yang terdiri dari pembangunan bak air bersih dan pembangunan jaringan irigasi tersier telah memberikan dampak terhadap kelancar aktifitas pertanian dan aktivitas pemenuhan kebutuhan air bersih.

Program pemberdayaan masyarakat di bidang pertanian dan peternakan telah memberikan dampak terhadap peningkatan pengetahuan masyarakat dalam mengelola ternak. Namun belum mampu diaplikasikan secara tepat. Dampak yang lain adalah meningkatkan kesadaran masyarakat dalam pemanfaatan pekarangan rumah maupun sekolah.

$$
\text { Program pemberdayaan }
$$
masyarakat di bidang pelatihan kejuruan telah memberikan dampak terhadap peningkatan kemanpuan, 
ketrampilan dan kreativitas masayrakat dalam menciptakan peluang usaha serta menjalankannya sesuai dengan potensi masingmasing secara maksimal.

Program pemberdayaan masyarakat di bidang pelatihan pemberdayaaan masyarakat memberikan dampak terhadap terbentuknya kelompok-kelompok usaha kecil masyarakat yang kreatif dalam pemanfaatan potensi lokal untuk dijadikan sebagai sumber penghasilan dibidang wirausaha.

Manajemen PT. STM perlu meningkatkan jangkauan, kuantitas, dan kualitas program pemberdayaan masyarakat.

Perlu ditingkatkan sosialisasi program terhadap semua stakeholder untuk menyatukan persepsi guna memastikan tujuan program tercapai sesuai dengan target yang di inginkan. Sosialisasi program akan meningkatkan partisipasi masyarakat.

Perlu ditingkatkan kualitas perencanaan, implementasi program dengan melakukan kemitraan dengan stakeholders lokal yg memiliki kompetensi sesuai dengan yang dibutuhkan.
Manajemen PT. STM harus lebih pro-aktif melakukan pengawasan terhadap semua kegiatan program pemberdayaan masyarakat untuk menjamin kualitas pencapaian program sesuai dengan yang di harapkan.

Diharapakan kepada manajemen PT. STM untuk mengsinergikan setiap alokasi dana pemebrdayaan masyarakatnya untuk menghindari overlapping pembiayaan dan meningkatkan efektivitas program sesuai dengan yang dibutuhkan oleh masyarakat.

Manajemen PT. STM disarankan untuk menggunakan lembaga perguruan tinggi untuk melakukan pendampingan program pemberdayaan masyrakat.

\section{DAFTAR PUSTAKA}

Basuki, Ari Satrio. 2007. Dampak Keberadaan Pertambangan Batu Bara PT Viktor Dua Tiga Mega terhadap Kondisi Sosial Ekonomi Masyarakat Disekitarnya (Studi Di Kecamatan Lahei Kabupaten Barito Utara Provinsi Kalimantan Tengah).

BPS (2013) Dompu dalam angka 
Ife, Jim. 2006. Community Developtment. Australia

Kartini, Dwi. 2009. Corporate social Responsibility. Bandung: PT. Refika Aditama

Katner. 1994. Administrasi pekerjaan Sosial.

Moleong, Lexy J. 2006. Metodologi Penelitian Kualitatif Bandung:RemajaRosdakarya.

Mulyadi (2004). Corporat Social Responsibility:

Mempertahankan Kembali Aspek Pemberdayaan, Keberpihakan dan Keberlanjutannya, Yogyakarta: Aditya Media bekerjasama dengan Jurusan Sosiatri Fisipol UGM. Edisi 1. (ISBN: 9793589 094)

Nuryana, Mu'man (2005). Corporate Social Responsibility dan Kontribusi Bagi Pembangunan Berkelanjutan, makalah yang disampaikan pada Diklat Pekerjaan Sosial Industri, Balai Besar Pendidikan dan Pelatihan Kesejahteraan Sosial (BBPPKS) Bandung, Lembang 5 Desember.

Nuryana, Mu'man (2007). Sumber Dana Sosial dari Corporate Social Responsibility Perusahaan. Badan Pelatihan dan Pengembangan Sosial Departemen Sosial RI. Seri IT: 02. (ISBN: 979-98374-64).
PT. STM (2012) Laporan program Program Pemberdayaan Masyarakat (Community Developmen).

PT. STM (2013) Laporan program Program Pemberdayaan Masyarakat (Community Developmen).

PT. STM (2014) Laporan program Program Pemberdayaan Masyarakat (Community Developmen).

Soedarsono, Bambang. 1990. Perkembangan Masyarakat Akibat Pertumbuhan Industri di daerah. Yogyakarta: Departemen Pendidikan dan Kebudayaan.

Sugiyono. 2010. Metode Penelitian Kuantitatif Kualitatif dan $R \& D$. Bandung: Alfabeta.

Salim HS. 2006. Hukum Pertambangan di Indonesia. Jakarta: PT. Raja Grafindo Persada.

Supancana. 2007. Analisis dan Evaluasi Hukum Tentang Pengembangan Masyarakat (community development) Dalam Kegiatan Usaha Pertambangan. Jakarta: Badan Pembinaan Hukum Nasional Departemen Hukum Dan Ham RI.

Suharto, edi. 2005. Kebijakan Sosial. Jakarta. 